\title{
A Modified Test Procedure to Measure Gas Permeability of Hollow Cylinder Concrete Specimens
}

\author{
Aissa Talah and Fettoum Kharchi
}

\begin{abstract}
The aim of this paper is to present a test procedure for the determination of gas $\left(0_{2}, N_{2}\right.$, air) permeability $\left(\mathrm{m}^{2}\right)$ of a hollow cylinder porous material specimen. It applies in particular, but not exclusively, for measuring gas permeability of hardened concrete specimens.

The gas permeability test in is carried out using a constant head permeameter. The design uses simple elements for easy measurements. This paper describes both the cell design and principles of operation of a novel aspect of experimental method and its application to the investigation of gas permeability of concrete. The form of concrete samples chosen reflects the present constructions cases where the permeability plays an important role in structures durability and security, such as nuclear power plants or storage structures.

This laboratory method applies to molded cylinders samples and drilled cores of concrete. This device is able to measure the permeability values between $10^{-20}$ and $10^{-15} \mathrm{~m}^{2}$.

The values obtained from this experimental procedure are similar to those found in literature.
\end{abstract}

Index Terms-Durability, gas permeability, measurement device, porous materials.

\section{INTRODUCTION}

In order to evaluate the applicability of such new materials and procedures, physical testing is necessary for the determination of durability parameters of structures. Two key parameters permeability and diffusivity are considered as durability indicators. The evaluation of durability and service life for concrete structures is very important. It has been extensively discussed in many papers [1], [4]. The durability of concrete structures is mainly affected by the transport of gaseous and liquid substances through its pore system

The ability of concrete to resist the penetration of the chemical agents such as chloride and sulfate ions is characterized by two physical quantities that are permeability and diffusivity. These two parameters are considered as "durability indicators".

The proposed experimental study is a part of a much wider research program, undertaken on the aging of cement matrix materials.

The present work focuses only on the determination of oxygen permeability coefficient of concrete specimens.

Manuscript received October 21, 2012; revised November 22, 2012. Thi work was supported by Built Environment research Laboratory (LBE), Civil Engineering Faculty, University of Sciences and Technology, Houari Boumediene (USTHB) (Algiers, Algeria.).We are grateful to many staff members of this Laboratory.

The authors are with the University of Sciences and Technology Houari Boumediene (USTHB), Algiers, Algeria (e-mail: talahay@ yahoo.fr, kharchifcong@ yahoo.fr).
Permeability is one of the most important characteristics of these materials, particularly for the case of storage structures. In fact, the increase in permeability and porosity of such materials is currently accepted as providing a reliable indication of their degradation (at least on a qualitative level) whether it can be of mechanical or physicochemical origins resulting from the cement matrix being attacked by aggressive substances [5], [6]. In a systematic research the structural changes due to water cement ratio have been studied using mercury porosimetry, nitrogen adsorption, oxygen diffusion and oxygen permeability [7]. When the concrete mixes were prepared with varying water cement ratios, different types of concrete were obtained with varying values of gas permeability.

In order to ensure the reliability of this method, an additional experimental test has been carried out on concrete samples of different water-cement ratios.

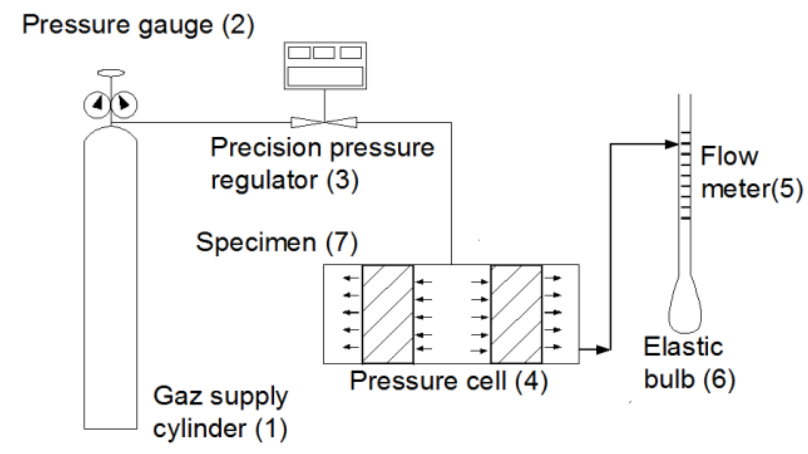

Fig. 1. Schematic layout of the experimental setup

\section{EXPERIMENTAL DEVICE}

The novel aspect of the experimental method has been designed and applied to porous materials such as ordinary and high performance concrete.

In particular, the proposed device differs from other devices by the cell, which is the main element of the experimental procedure as well as by elimination of confining pressure and by elimination of air cylinder.

The originality of this experiment lies in the shape of the sample that is a hollow cylinder which reflects the actual construction cases. The test principle is to maintain continuous gas flow through the sample under steady conditions.

Fig. 1 depicts the conceptual design of a constant head permeameter to allow rapid and accurate measurement of permeability of the specimen. In this example, the permeameter includes a bottle of oxygen (1) with a pressure gauge (2) connected to a pressure regulator (3) which can maintain the pressure with a tolerance of $0.01 \mathrm{MPa}$. The Cell 
(4) containing the specimen is connected in series with the regulator and the flowmeter (5) by a flexible tube.

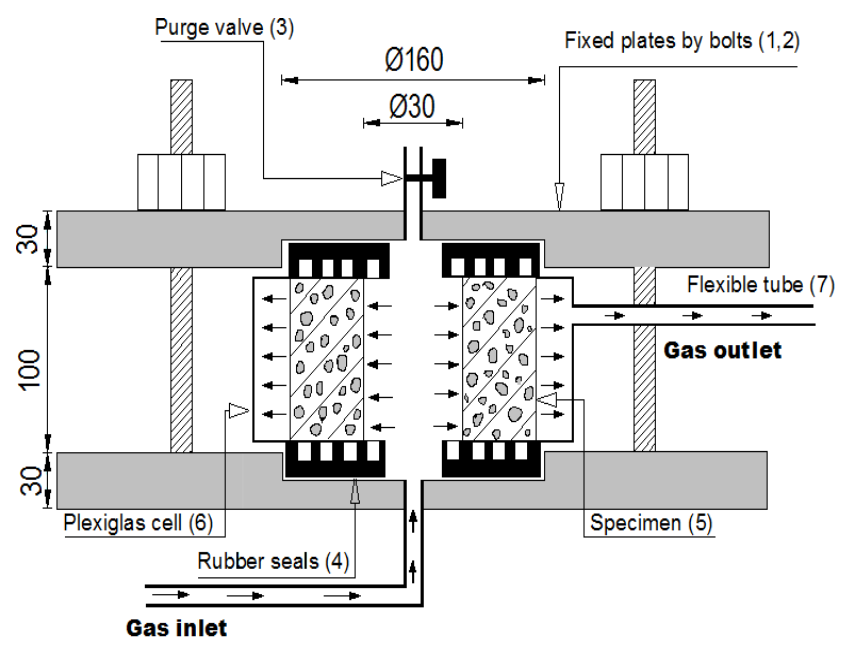

Fig. 2. Schematic representation of the cell.

Fig. 2 shows the cell section, consisting of two cylindrical plates $(1,2)$ of the same diameter. One plate is mobile while the other is fixed. The top plate is fitted with a valve (3) to evacuate air occluded in the hollow cylindrical test-specimen. These plates are covered with a rubber sealing strip (4) to ensure a good seal between the two cylindrical plates $(1,2)$ and the specimen (5). The test specimen (5) is surrounded by a plexiglas cell (6) sealed and connected laterally to flexible tube (7) and to the flowmeter (5). Flowmeter includes an elastic bulb (6) with soapy water. By exerting pressure on the bulb, a bubble rises, driven by the flow of outgoing gas and the graduated tube, permitting then to measure the gas flow. The input pressure can be chosen between $0.1 \mathrm{MPa}$ and 0.8 $\mathrm{MPa}$ with an accuracy of $0.01 \mathrm{MPa}$.

This experimental device may be used for the following tests:

Measuring a single pressure value (typically $0.2 \mathrm{MPa}$ ) to evaluate the apparent permeability of the material $\left(\mathrm{K}_{\mathrm{a}}\right)$;Measuring more than two successive pressure (typically 0.2 $\mathrm{MPa}, 0.3 \mathrm{MPa}$ and $0.5 \mathrm{MPa}$ ) with calculation of the intrinsic permeability of the material $\left(\mathrm{k}_{\mathrm{i}}\right)$ [8].

The specimens of variable diameters required for measurements of permeability are molded and cored cylindrical concrete specimens. The proposed cell can be manufactured to fit samples of any dimension. The cell may also be used for any other type of solid porous material.

The permeameter must be installed in an air-conditioned room $\left(T=20 \pm 1^{\circ} \mathrm{C}\right.$ and relative humidity $\left.=65 \pm 5 \%\right)$.

\section{GAS PERMEABILITY MEASUREMENTS}

The test consists of maintaining the test specimen at a constant pressure of oxygen gas. The apparent permeability $\left(\mathrm{k}_{\mathrm{a}}\right)$, in $\mathrm{m}^{2}$, is calculated at constant pressure using the

Hagen-Poiseuille expression for a compressible fluid. Since gases are compressible, the inlet pressure $\mathrm{P}$ (applied test pressure (absolute)) at which the flow rate $(\mathrm{Q})$ is measured must be taken into account in addition to the outlet pressure $\mathrm{P}_{\mathrm{atm}}$ (atmospheric pressure). All pressures are absolute values expressed in $\mathrm{N} / \mathrm{m}^{2}$ [9]. The apparent permeability coefficient $\left(\mathrm{K}_{\mathrm{a}}\right)$ for the special design of the concrete specimens is given by the following equations.

$$
K_{a}=\left(2 \cdot Q \cdot P_{a t m} \cdot L \cdot \mu\right) /\left(P^{2}-P_{a t m}^{2}\right) A
$$

In this present case; $\mathrm{A}$ is given by

$$
A=\int_{R_{1}}^{R_{2}}(2 \cdot \pi \cdot h \cdot R \cdot d R) / L=\pi \cdot h \cdot\left(R_{2}^{2}-R_{1}^{2}\right) / L
$$

The apparent permeability relation becomes

$$
\begin{array}{r}
K_{a}=\left(2 \cdot Q \cdot P_{a t m} \cdot L \cdot \mu\right) /\left(P^{2}-P_{a t m}^{2}\right) \pi \cdot h \cdot\left(R_{2}^{2}-R_{1}^{2}\right) / L \\
K_{a}=\left(2 \cdot Q \cdot P_{a t m}\right)\left(R_{2}^{2}-R_{1}^{2}\right) \mu /\left(P^{2}-P_{a t m}^{2}\right) \pi \cdot h \cdot\left(R_{2}+R_{1}\right)
\end{array}
$$

where: see Fig. 3.

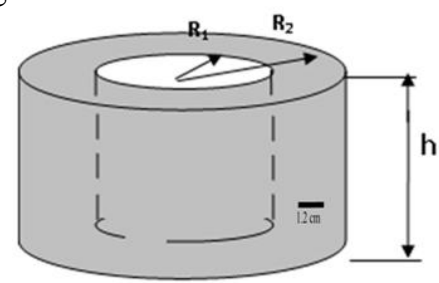

Fig. 3. Specimen

$h=$ specimen thickness (m);

$A=$ cross-sectional Area $\left(\mathrm{m}^{2}\right)$;

$L=R_{2}-R_{1}$ : length of the section of sample crossed by the flow (m);

$R_{1}=$ inner radius;

$R_{2}=$ outer radius;

$\mu$ =gas dynamic viscosity $\left(\mathrm{Ns} / \mathrm{m}^{2}\right)$.

For oxygen, $\mu=20,2.10^{-6} \mathrm{Ns} / \mathrm{m}^{2}$ at $20^{\circ} \mathrm{C}$.

Intrinsic permeability $\left(K_{i}\right)$ is defined by Klinkenberg [10] as the $y$-intercept of the line connecting the permeability and the inverse of the average pressure $P_{m o y}$, with

$$
P_{\text {moy }}=\left(P_{\text {atm }}+P\right) / 2 .
$$

The method used for determining the intrinsic permeability coefficient $\left(K_{i}\right)$, consists of measuring $K_{a}$ at different pressures and plotting it against the inverse of the mean pressure. The intrinsic permeability value can be a better parameter for characterization of a concrete for durability compared to the traditional Darcy's coefficient of permeability, as it is independent of the fluid properties and the applied pressure gradient. It is hence, a characteristic of the porous medium alone. It may allow us to make a better comparison of values obtained under different experimental conditions [8], [9].

\section{TEST PROGRAM}

\section{A. Materials}

The materials used in this investigation are Portland cement, natural pozzolan, aggregate, water and a superplasticizer.

Portland cement (CPA-CEM-I / A 42.5) conforming to the European standard EN197-1[11] and natural pozzolan were used as cementitious materials. The chemical compositions and physical properties of the cement and the pozzolan are given in Table I. The natural volcanic pozzolan extracted 
from the deposit was finely crushed and has a Blaine fineness modulus of $960 \mathrm{~m}^{2} / \mathrm{kg}$ and an absolute density of $22.6 \mathrm{KN} / \mathrm{m}^{3}$.

Crushed limestone coarse aggregates with a maximum size of $16 \mathrm{~mm}$, and a specific gravity of 2.70 , and natural sand with a specific gravity of 2.60 were used for the concrete samples. Both aggregates were obtained from local material. The size grain, the fineness modulus $(\mathrm{FM}=3.2)$, the sand equivalent value $(\mathrm{SEV}=97 \%)$ and resistance to shocks $(33 \%)$ show that gravel and sand can be used for developing a high performance concrete (HPC) [12].

TABLE I: THE ChEMICAL COMPOSITIONS (\%) AND PHYSICAL PROPERTIES OF CEMENTITIOUS MATERIALS USED

\begin{tabular}{llc}
\hline \hline Item & CEM-I & Pozzolan \\
\hline $\mathrm{SiO}_{2}$ & 21.28 & 44.95 \\
$\mathrm{Al}_{2} \mathrm{O}_{3}$ & 3.85 & 16.91 \\
$\mathrm{Fe}_{2} \mathrm{O}_{3}$ & 4.61 & 9.47 \\
$\mathrm{CaO}$ & 63.05 & 14.59 \\
$\mathrm{MgO}$ & 1.19 & 3.70 \\
$\mathrm{SO}_{3}$ & 2.54 & 0.20 \\
$\mathrm{Na}_{2} \mathrm{O}$ & 0.18 & 1.34 \\
$\mathrm{~K}_{2} \mathrm{O}$ & 0.80 & 1.35 \\
$\mathrm{Cl}^{-}$ & 0.01 & - \\
Insoluble residue & 1.11 & 0.56 \\
Loss on ignition & 1.58 & 0.30 \\
Specific gravity $(\mathrm{g} / \mathrm{cm} 3)$ & 3.10 & 2.26 \\
Specific surface area m2/kg & 322 & 960 \\
\hline \hline
\end{tabular}

The main idea is to develop a dense concrete from a most compact skeleton granular and a possible content of cement and water compatible with the required strength, durability and workability.

The practical and simple method "Dreux-Gorisse" based on the size analysis (sand and gravel different fractions), will be used in this study [13]. In order to investigate the effect of natural pozzolan on the performance properties of concrete, two different concrete mixes were employed: ordinary concrete (OC) and high performance concrete (HPC). Details are given in Table II. The dimensions of hollow cylindrical test-specimen are shown in Fig. 2.

TABLE II: MIX PROPORTIONS AND PROPERTIES OF CONCRETE

\begin{tabular}{lccc}
\hline \hline Item & & O.C & H.P.C \\
\hline W/C & Ratio & 0.50 & 0.27 \\
Cement & $\left(\mathrm{kg} / \mathrm{m}^{3}\right)$ & 425 & 393 \\
Pozzolana & $\left(\mathrm{Kg} / \mathrm{m}^{3}\right)$ & 0.00 & 032 \\
Water & $\left(\mathrm{Kg} / \mathrm{m}^{3}\right)$ & 212 & 100 \\
Sand & $\left(\mathrm{Kg} / \mathrm{m}^{3}\right)$ & 788 & 788 \\
Gravel 3/8 & $\left(\mathrm{Kg} / \mathrm{m}^{3}\right)$ & 163 & 163 \\
Gravel $8 / 16$ & $\left(\mathrm{Kg} / \mathrm{m}^{3}\right)$ & 886 & 886 \\
SP & $(\%)$ & 0.00 & 1.50 \\
air content & $(\%)$ & 2.00 & 1.70 \\
Slump & $(\mathrm{cm})$ & 007 & 018 \\
Density & $\left(\mathrm{Kg} / \mathrm{m}^{3}\right)$ & 2480 & 2576 \\
& & & \\
\hline \hline
\end{tabular}

SP: Superplasticizer (wt.\% of total cementitious content)

The control mix contained only Portland cement as binder. In the HPC, Portland cement was partially replaced with, respectively, $7.5 \%$ of natural pozzolana (by weight of cement) obtained by optimization tests.

The super plasticizer content (naphthalene based with a specific gravity of 1.2 and a solid content of 30\%) was determined from an extensive series of optimization tests and added at the time of mixing.

All concretes were mixed in accordance with ASTM C192 standard [14] in a power-driven revolving pan mixer.

\section{Pre-Conditioning OF SPECIMENS}

The gas permeability of a concrete specimen depends on the porous structure of the material and also on its degree of water saturation. The permeability of concrete can be determined only if the specimen is dried, so the gas can pass through this sample. The value of gas permeability of materials cannot be measured on a saturated sample, because the volume of voids is filled with water. In order to compare the results, the experimental procedure used is similar to that recommended by the Cembureau method [15].

The calculation of the intrinsic permeability is done by applying the Klinkenberg method [13].

\section{Test Results}

Since gas permeability can be regarded as an indicator of durability, the test described in this paper is applied in many research works on concrete durability. The large number of tests on a wide range of materials has also helped to build up a database and verify the reliability of the procedure.

TABLE III: GAS PERMEABILITY OF DIFFERENT CONCRETES AT DIFFERENT AGES $(P=0.2 \mathrm{MPA})$.

\begin{tabular}{lcccc}
\hline \hline days & $\begin{array}{c}\text { O.C } \\
\text { C.S }{ }^{\mathrm{b}} \text {.(MPa) }\end{array}$ & $\begin{array}{c}\text { O.C. } \\
\mathrm{K}_{\mathrm{a}}\left(10^{-18} \mathrm{~m}^{2}\right)\end{array}$ & $\begin{array}{c}\text { H.P.C } \\
\text { C.S } \text { b }^{\mathrm{C}}(\mathrm{MPa})\end{array}$ & $\begin{array}{c}\text { H.P.C } \\
\mathrm{K}_{\mathrm{a}}\left(10^{-18} \mathrm{~m}^{2}\right)\end{array}$ \\
\hline 28 & 30 & 320 & 50 & 205 \\
90 & 45 & 274 & 68 & 170 \\
180 & 50 & 244 & 80 & 78 \\
365 & 55 & 180 & 88 & 46 \\
\hline \hline
\end{tabular}

${ }^{\mathrm{b} C . S .:}$ Compressive Strength

Results presented in Table III, show that the apparent permeability tends to decrease when the compressive strength increases, which is the most frequent case.

TABLE IV: GAS PERMEABILITY OF DIFFERENT CONCRETES SiX MONTHS IN AGE.

\begin{tabular}{ccccc}
\hline \hline $\begin{array}{c}\text { Specimen } \\
\text { code }\end{array}$ & $\begin{array}{c}\text { Inlet pressure } \\
(\mathrm{MPa})\end{array}$ & $\begin{array}{c}\text { Outlet pressure } \\
(\mathrm{MPa})\end{array}$ & $\begin{array}{c}\mathrm{K}_{\mathrm{a}} \\
\left(10^{-18} \mathrm{~m}^{2}\right)\end{array}$ & $\begin{array}{c}\mathrm{K}_{\mathrm{i}} \\
\left(10^{-18} \mathrm{~m}^{2}\right)\end{array}$ \\
\hline \multirow{2}{*}{ C50 } & 0.2 & 0.1 & 244 & \\
& 0.3 & 0.1 & 235 & 210 \\
\hline \multirow{2}{*}{ C80 } & 0.5 & 0.1 & 227 & \\
& 0.2 & 0.1 & 78 & 53 \\
& 0.3 & 0.1 & 73 & \\
\hline \hline
\end{tabular}

Table IV shows the determination of the apparent and the intrinsic permeability values for two concrete types (C50 and C80) obtained by the modified procedure method. Results 
from this experimental procedure as shown in table IV confirm the decrease of coefficient $\mathrm{k}_{\mathrm{a}}$ when the pressure increases.

Table IV shows the results of the intrinsic permeability by Klinkenberg method [10] for two concrete types after drying at $105^{\circ} \mathrm{c}$. Results confirm the decrease of coefficient $k_{i}$ when the compressive strength increases.

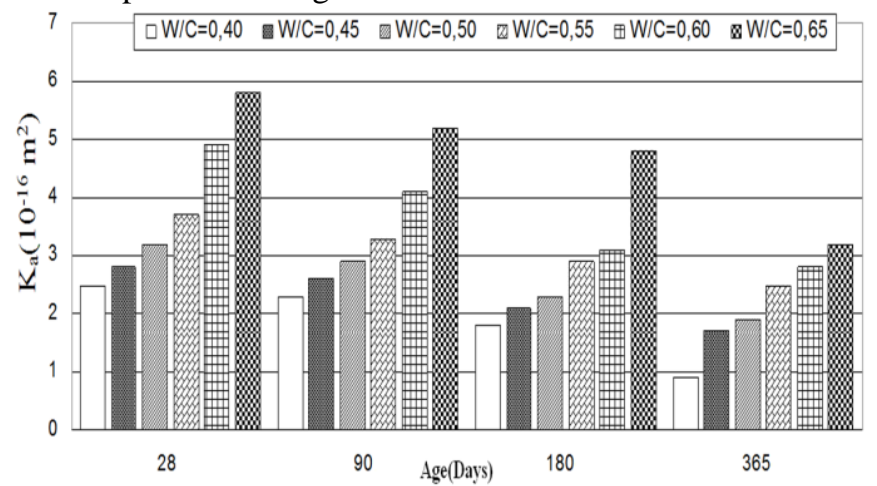

Fig. 4. Determination of the apparent gas permeability at an inlet of 0,3 MPa of concrete Samples of different Water/cement ratios.

Fig. 4 shows the influence of w/c ratios on the apparent gas permeability $\mathrm{K}_{\mathrm{a}} \cdot\left(\mathrm{x} 10^{-16} \mathrm{~m}^{2}\right)$ measured on concrete samples for different water/cement ratios and at different ages. For this purpose, only the results of the tests with an inlet pressure of $0.3 \mathrm{MPa}$ and at saturation degree of $(0 \%)$ will be discussed.

Mixes of same ordinary concrete have an increasing w/c ratio, from 0.4 to 0.65 .

The amount of cement is kept constant, but the amount of water is varying.

The higher the amount of water, the higher the excess of water not used in the hydration process, causing a higher capillary porosity [16]. According to the experiments, increasing the water-cement ratio, indeed gives an increase in porosity and an increase in oxygen permeability.

The results obtained reinforce the conformity of the procedure test and indicate that hollow cylindrical specimens can be used to measure the gas permeability of concretes.

\section{CONCLUSION}

The work undertaken allowed the following conclusions:

1) The experimental procedure to evaluate the gas permeability of a porous material is presented and verified by means of tests. The reliability of using this procedure is demonstrated by typical experimental measurements on a porous material compared with those obtained from literature.

2) The device is characterized by the fact that the lateral enclosure of cell is influenced only by the atmospheric pressure, which eliminates the damage risks.

3) The device is characterized by the fact that the chosen form of concrete sample reflects the present building constructions where the permeability plays an important role in the durability and security of structures, such as in nuclear power plant or storage structures.

4) The device is characterized by the fact that the air trapped in the hollow cylindrical concrete specimen is quickly evacuated by the relief valve incorporated at the higher plate of the cell.

5) The inlet gas pressure $(\mathrm{P})$ in the cell is applied onto the inside surface of the hollow cylinder which eliminates the problems of confinement pressure, which may distort the results.

\section{REFERENCES}

[1] A. Sarja, "Durability design of concrete structures-committee report130-CSL," Material and Structure, vol. 33, pp. 14-20, 2000

[2] M. T. Liang, K. L. Wang, and C. H. Liang, "Service life prediction of reinforced concrete structures," Cement and Concrete Research, vol. 29, pp.1411-1418, 1999

[3] C. J. Hookham, "Service life prediction of concrete structures. Case histories and research needs," Concrete International: Design and Construction, vol. 14, no. 11, pp. 50-53, 1992.

[4] L. Sentler, "Service life predictions of concrete structures," Durability of Building Materials. vol. 5, no. 1, pp. 81-98; 1987.

[5] R. J. Detwiler, J. D. Brian, and B. Robert, "Assessing the durability of concrete in freezing and thawing," American Concrete Institute, Materials Journal, vol. 86, pp. 29-35, 1989.

[6] J. H. Bungey and S. G. Millard, Testing of Concrete in Structures, third Ed, Chapman and Hall, New York, 1996, pp. 286

[7] G. Veneziano, "Physics briefs: Energies, physic and mathematic," American Institute of Physics, vol.12, no. 1, 1990.

[8] A. Abbas, M. Carcasses, and J. P. Ollivier, "Gas permeability of concrete in relation to its degree of saturation," Material and Structure. vol. 32 , no. 215 , pp. 3-8, 1999.

[9] J. J. Kollek, "The determination of permeability of concrete by cembureau method a recommendation," Material and Structure vol. 22, pp. 225-230, 1989

[10] J. Klinkenberg, "The permeability of porous media to liquids and gases," API Drilling and Production Practice, USA, 1941. pp. 200-213.

[11] NF EN 197-1 Cement-part 1: Composition, specifications and conformity criteria for common cements, AFNOR. 2001.

[12] R. Lanchon, Cours De Laboratoires, Bétons et Sols, editions desforges, Paris, 1983.

[13] G. Dreux and J. Festa, Nouveaux Guide De Béton et De Ses Constituants, editions eyrolles, Paris, 1998.

[14] Standard Practice for Making and Curing Concrete Test Specimens, Annual Book of ASTM Standards, vol. 4, no. 2, 2003.

[15] H. K. Hilsdorf and J. Kropp, "Permeability of concrete as a criterion of its durability," Recommendations Materials and Structures, vol. 32, pp. 174-179, 1999.

[16] V. Boel and G. De Schutter, "Porosity of superplastized cement past containing limestone filler," Advances in Cement Research, vol 18, pp. 97-102, 2006

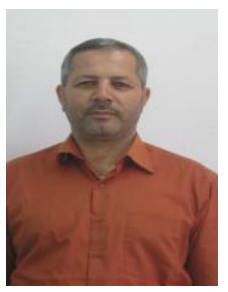

Aissa Talah received his Engineer's degree in Civil Engineering from Annaba University, Algeria in 1983 $\mathrm{He}$ is received his $\mathrm{Ph} . \mathrm{D}$ in Civil Engineering, option materials from University of Science and Technology, Algeria in 2012. He is a researcher teacher at Laboratory Built in the Environment, Faculty of Civil Engineering, University of Science and Technology of Algiers, Algeria. $\mathrm{He}$ is currently an Associate Professor in the department of materials and structures (USTHB). He has 25 years of teaching experience at University. He has published two papers in ICJ journals and in Revue Shynthèse. His main interests are in Materials, Durability of Structures and permeability of concrete.

Fettoum Kharchi is a professor and Director of Research at the University of Sciences and Technology, Houari Boumediene (USTHB) Built Environment research laboratory LBE-Faculty of Civil Engineering, in Algiers- Algeria. She is engineer from polytechnic school of Algiers 1982 and Doctor from INSA Toulouse, France 1987. Her research interests are concrete (material and structures). She is fondator member of ACI chapter in Algeria. 